Rockefeller Foundation.

However, several academic researchers contest the plan to concentrate funding in the hands of a few groups. They argue that this could be a "lottery" that might exclude high-quality research projects, and "put all our eggs in one basket".

But Evans opposes excessive dispersion of grants, arguing that MMV amounts to a venture capital fund: "Venture capitalists are hunters who go out and see what is in the pipeline, and how these can be turned into products. What you want is a consensus as to who are the best and brightest and what the best investment portfolio would be."

Another uncertainty is the depth of industry commitment to MMV. The proposal is supported by both the IFPMA and the Hever group, an informal grouping of the research directors of the major pharmaceutical companies. At least three companies, including Glaxo-Wellcome, have also agreed to take part in the drug-discovery phase.

Sargent argues that more industry support will be forthcoming, but that it is difficult to make "tangible commitments" until discussions on specific projects are completed.

The Doldor group, an informal grouping of the chief executive officers of the major drug companies, last year rejected an earlier version of MMV. This had proposed that financing should come largely from a consortium of private companies, and the private sector still seems reluctant to commit cash.

One reason is that industry is concerned that financing such ventures directly could set a precedent, leading to pressure for similar ventures in other, more profitable therapeutic areas.

Rob Ridley, a researcher at Hoffmann-La Roche on secondment to WHO to develop $\mathrm{MMV}$, is one of several observers who argue that the value of the "in kind" pledges already obtained from several companies should not be underestimated. Indeed, the MMV proposal estimates that such contributions could cut the cost of developing drugs for malaria from around $\$ 500$ million to $\$ 186$ million.

The acid test for industry's commitment will come when their support is required to take drugs from the MMV laboratory to the marketplace - the most expensive part of the drug development process. At present, this part of the MMV proposal is "very vague", says one funding agency official.

A carrot for industry being considered by the World Bank as part of MMV would involve subsidizing bulk antimalarial drug purchases by poor countries to create a market for industry. "If MMV is going to succeed, a clear commitment from the World Bank would be needed", says Sargent.

In principle, such subsidies may be relatively straightforward to arrange using existing mechanisms, according to Amie Batson, who is the World Bank's representative on MMV.

Declan Butler

\title{
Energy department under fire on pace of reforms
}

[WASHINGTON] The US Department of Energy (DoE) was told last week that it has not responded quickly enough to the 1995 Galvin Report, which scathingly criticized the efficiency of its huge network of research laboratories.

The report, prepared by an outside panel led by Bob Galvin, the chairman of Motorola, called for sweeping reforms to clarify the objectives of the department's laboratories and reduce their operating costs by as much as a half (see Nature 373, 463; 1995).

But at a hearing of the House Science Committee, the department was attacked mercilessly for its alleged sloth in implementing reforms. The criticism was based on the findings of a report commissioned by the General Accounting Office (GAO), the investigative arm of Congress.

Ken Calvert (Republican, California), chair of the energy subcommittee of the science committee, described the efforts as "baby steps where giant steps are required". Department officials "have done everything to drag their feet and not to implement even modest reforms", said Tim Roemer (Indiana), senior Democrat on the same subcommittee.

In contrast, those working at the laboratories - who have witnessed many changes in their working environment since 1995 - are surprised at the GAO's conclusions. Several laboratories claim that their overhead costs have fallen by as much as a third in that time.

Ernest Moniz, the undersecretary of energy with responsibility for science and technology, told the hearing that reforms undertaken after the Galvin report would save \$2.2 billion over five years. "From our perspective there has been a lot of progress," he said. "Rome wasn't built in a day." The DoE's complex of 23 major laboratories employs 60,000 people and costs $\$ 10$ billion a year to operate.

John McTague, chief technical officer at the Ford Motor Company who co-chairs with Moniz the Laboratory Operations Board, established by the DoE to implement the reforms, told the hearing that change is underway, albeit slowly. McTague cited instability at the top of the DoE - the last secretary, Federico Peña, stayed for only 15 months - as a "major problem" in implementing change.

The GAO agrees that the Laboratory Operations Board has had a positive influence, but says the board lacks the clout to implement reforms. "It is still advisory and cannot coordinate or direct specific actions," the GAO points out.

Bruce Tarter, the director of the Lawrence Livermore National Laboratory in California, says the board has been "a very good thing" for the laboratories. "It has had a very

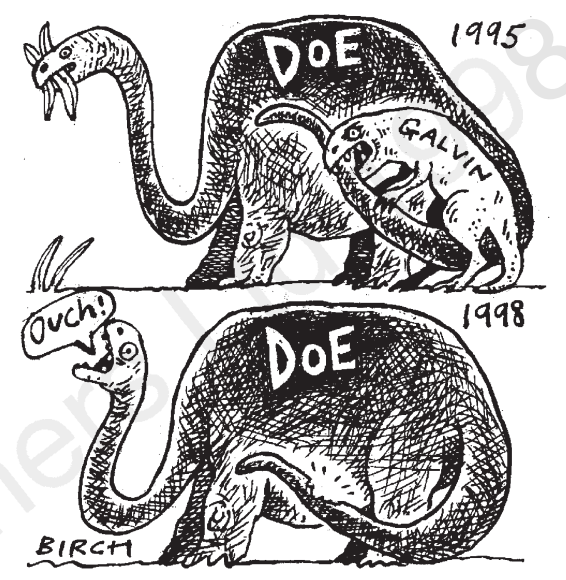

positive impact," he says. "The tricky part will be to maintain that."

At its most recent meeting, on 9 September, the board received a positive report from Paul Gilman of the National Research Council about the standard of peer review at the laboratories, something the Galvin report called into question.

"Merit review is pervasive in the department, and that isn't what the man on the street would think," said McTague. "There are many people in the universities who believe exactly the opposite of what's in [Gilman's] report."

Furthermore, many of the laboratories claim to have achieved sharp reductions in overhead costs in recent years. Phillip Schultz, the Lawrence Livermore laboratory controller, for example, says a 1994 initiative designed to "shine a light" on its costs has already cut overheads at the laboratory from 32.5 per cent then to 23.3 per cent this year.

Schultz's finance department has shrunk from 200 people to 140 in the process, and $\$ 40$ million a year that used to be spent on overheads has been freed up for scientific programmes there, along with another $\$ 10$ million for laboratory maintenance.

The GAO argues that most actions of this sort have been taken at the initiative of the laboratories rather than the DoE.

In contrast, Bill Madia, director of the Pacific Northwest National Laboratory, says the department "has got to be given credit" for a shake-up there which, he says, cut its overhead costs by $\$ 60$ million in just 18 months after he arrived as director.

But Victor Rezendes, director of energy and science issues at the GAO and main author of its report, is sceptical about such claims. "When you consider overheads, what they do is like squeezing a balloon," he says. "The onus now is on the Congress: there doesn't seem to be an impetus for change at DoE."
ColinMacilwain 